ISSN: 2638-6062

\title{
The Introduction of Time in History
}

\author{
Patrice F Dassonville* \\ Department of physics and chemistry, France
}

Received: 眥 November 09, 2018; Published: November 15, 2018

*Corresponding author: Patrice F Dassonville, Department of physics and chemistry, France

\begin{abstract}
The invention of time has gradually changed the way of living as well as the way of thinking. As for history, time quickly became an indispensable component of investigation and analysis. Some great classical historians provide an interesting illustration.
\end{abstract}

Keywords: Event ; Chronology; Anachronism

\section{Introduction}

Between 4500 and 4800 years ago the Sumerians became aware of the repetition of the movement of the Moon. From this observation, that we call "lunation », they invented the lunar month [1] and they used it as a unit in their everyday life : this is the first trace of time in history. The Sumerians could not imagine that time was going to upset the knowledge and in particular the way of studying history.

\section{The Confusion between Time and Events}

History is conceptual instead of phenomenonal. There are no jolts of history and it's an error to claim that history as such has an active role on events. Instead, events act on events. Palingenesis is a Stoic concept of " cyclic return of events ». It is a nonsense when translated in everyday language by " times are repeating ", instead of « events are repeating ». The historian transcribes and analyses past events and present events. Stricktly speaking, it comes neither to past time, nor to present time. Instead of « times to come », we should say « the events to come », because the idea is related to events not to time. In The War of Jews versus Romans, the Jewish historian Flavius Josephus (37-100) refered to « those who undertake to write history and to enlight things that time length has obscured » [2] (Book XIV). The Greek founder of history, Herodotus (484-425), prefaced the Book I of his Historical Survey : « Herodotus of Halicarnassus presents the results of his survey, in order that time does not abolish men's works and to ensure that great exploits do not fade into oblivion » [3].

In Rome, there was no reference event, then for each year the text began by : Under the consulate of... The Roman historian Tacitus (c. 56-120) envied these great historians who have described major events. His Annals (from Latin annales) are an annual narrative of the facts according to the consular chronology: Facts, minor at first view, but which often produce great events [4] (Book IV, Ch. XXXII, 2). The narrating of the events was drafted by the magistrates and recorded in the Journal of the Acts called acta senatus. Tacitus explained how the Romans drafted an infinite number of laws, and the diversity of the current laws [4] (Book III, Ch. XXV, 2). They engraved their laws on stone tables and their archives on copper tables, in order to preserve them inside the Capitol. In the preface of his Historical Library, Diodorus of Sicily (c. 90-30) confided : we looked carefully records held by Romans for so long, in order to clarify the history of this huge empire [5].

\section{The Concern for Historical Rigor}

In The Peloponnese War, the Greek founder of historical science, Thucydides (c. 465-c. 395) wrote : «We should not make more instances with poets, who have enlarged events of that time, for the purposes of their art, as well as logographers writing history, which were more concerned to seduce their audience than to establish the truth » [6] (Book I, 20 \& 21). We know that Herodotus quipped on Homer (Book II, 23). In Parallel Lives, the Greek biographer Plutarch (c. 46-c. 126) emphasizes « the strong foundation of history that builds on facts » [7] (Life of Thesus 1,2) and he observes that those who write long after the events have in front of them the veil of elapsed time that steals their knowledge [7] (Life of Pericles 13,16). He writes that in for composing a historical work, it's necessary to live in a famous city to access books and to interview witnesses [7] (Life of Demosthenes, 2,1). The Roman encyclopedist Varron (116-27) was considered by Plutarch as the most scholarly among historians. [7] (Life of Romulus 12,3). 


\section{Chronology}

Plutarch uses the word chronology, from Latin chronicus, that is the ranking of events in the order of their occurrence : hypothesis that contradicts the chronology [7] (Life of Cimon 4,10). But he finds that the chronological tables are confusing [7] (Life of Themistocles 27,2 ; Life of Camillus 22,2). The Latin poet Horace (65-8 BCE) enters a reservation : the one who makes chronology, judges the merit only through years [8] (Epistles, Book II, I). In Cicero, the Latin scholar (106-43), conservatis temporibus, " respecting time » means « respecting chronology » [9]. Chronology was revolutionized by the invention of time units, that replaced the reigns of monarchs, the seasons, the position of planets, the consular years in Rome, the Olympiads in Athens.

\section{The Anachronism in History}

An anachronism results from an error in chronology, or an incompatibility with the era, or the rewriting of history with current knowledge. Time can be an effective way to avoid such mistakes. Let's mention three examples of anachronisms in Art :

a) The tradition lets supposed that Moses might have lived during $13^{\text {th }}$ century BCE. The first consonantal linear writing appeared in Phoenicia during the $11^{\text {th }}$ century BCE and the consonantal Hebrew appeared during the $9^{\text {th }}$ century BCE [10] : therefore the representations of the Tables of the Law with a text in Hebrew, by Rembrandt (1606-1669) is an anachronism. The spanish painter José Ribera (1591-1652) represents the Tables of the Law engraved in Greek writing, although the ancient Greek writing derived from Phoenician writing during the $11^{\text {th }}$ century BCE. In fact the Tables of the Law should be engraved either with hieroglyphic Egyptian characters (c. 3000 BCE), or with hieratic Egyptian characters (c. 2400), or with Ugaritic cuneiform characters $\left(14^{\text {th }}-13^{\text {th }}\right.$ BCE $)$.

b) The representation of Adam and Eve with a navel, by Dürer (1504), Titian (1550), Cranach the Elder (c. 1513), Masaccio (1527), Jan Brueghel the Younger (c. 1650), are interesting illustrations of anachronism. c) Jesus child in adoration before the cross by the Le Nain brothers (c. 1645) is another example of anachronism in art (Private collection).

The appropriate corrections can be made thanks to time. Highly sophisticated methods such as the Carbon14 protocol, the measurement of tooth wear on a fossil, the study of larvae on a cadaver, allow archaelogy or forensic sciences to obtain more and more precises datings.

\section{Conclusion}

The fall of the Berlin Wall has led some authors like the US economist Francis Fukuyama, to say that it was «the end of history» : browse through a history book shows that Humanity is inherently conflictual ; and fortunately, history is not only made with conflicts. The anthropology and the ethnography have demonstrated that « people without time » have a history [11], because history is tied to events, whatever they are. However, the invention of time has allowed the advent of historical science.

\section{References}

1. Conteneau G (1937) La Civilisation d'Assur et de Babylone. Payot p. 9195.

2. Flavius Josephus (1968) La Guerre des Juifs contre les Romains. Lidis.

3. Herodotus (1964) L’Enquête. Gallimard.

4. Tacitus (1993) Annales. Gallimard.

5. Diodorus La Bibliothèque Historique. Remacle.

6. Thucydides (1964) La Guerre du Péloponnese. Gallimard.

7. Plutarch (2001) Vies Parallèles. Robert Laffont.

8. Horace (1967) Épitres. Flammarion.

9. Gaffiot F (2000) Dictionnaire Latin-Français. Hachette.

10. Réunion des Musées Nationaux (1982) Naissance de l'écriture, cunéiformes et hiéroglyphes.

11. Dassonville P (2017) The Invention of Time \& Space. Springer.

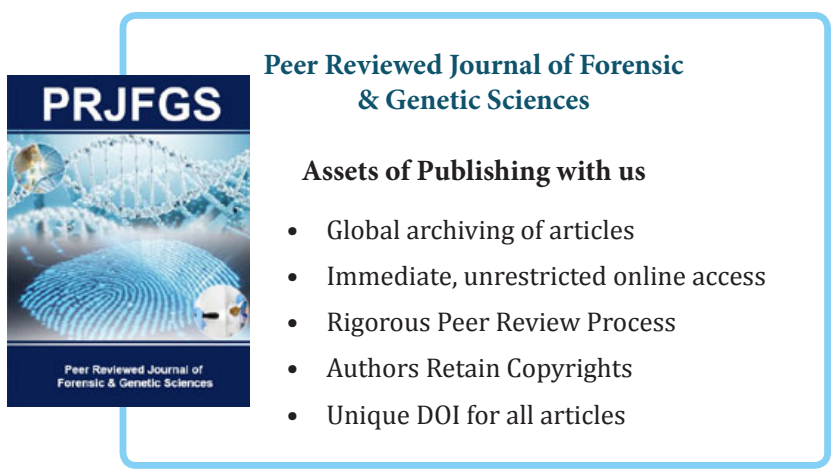

